\title{
Muslims in Europe, Sixteenth to Eighteenth Centuries
}

The Muslim presence in Central and Western Europe during the sixteenth, seventeenth, and eighteenth centuries was greater than had been thought, at least up to a few years ago. Eastern Europe, of course, was an entirely different case, especially in the Balkans, ruled by the Ottoman Empire - though it began to lose territory in the 170os - and in large regions of southeastern Europe that were gradually absorbed into the Russian Empire. In certain areas of these territories Muslims either ruled or formed a majority, while in others they were a significant minority. Nor did they disappear from Balkan lands altogether, for there are still nuclei of Muslim populations outside the small area of European Turkey, as well as in much of southern Russia. We shall not be concerned with those cases here, however, since they are substantially different from those of Western Europe. ${ }^{1}$

As to Central and Western Europe, it has been and to some extent continues to be thought that the Muslim presence in the Early Modern period was scarce and brief, and therefore insignificant. ${ }^{2}$ But recent research has proved that it was much more significant than has been acknowledged until now. The step from seeing Muslims as a groupe invisible to regarding them as étrangers familiers represents a significant advance in our understanding of the matter. We now have monographs on a considerable swath of European territory that show a good number of Muslims either visiting or living there for varying periods of time and many different reasons. ${ }^{3}$ We also have overall views for a few countries, particularly France, ${ }^{4}$ Great

1 Planhol, Les nations du Prophète/Las naciones del Profeta; Mantran, Histoire de l'Empire musulman.

2 In the long medieval period, Muslims occupied not only Spain and Portugal but Sicily, Malta, and more intermittently southern France and Otranto.

3 Matar, In the Lands of the Christians, Europe Through Arab Eyes, and "Europe Through Eighteenth-Century Moroccan Eyes"; Dakhlia, "Assujettis au baptême?"; Dakhlia and Kaiser, Les musulmans dans l'histoire de l'Europe. II. Passages et contacts; Dakhlia and Vincent, Les Musulmans dans l'histoire de l'Europe. I. Un intégration invisible; Valensi, Ces étrangers familiers; Lewis, The Muslim Discovery of Europe/Comment l'Islam a découvert l'Europe.

4 Dakhlia, "Musulmans en France"; Poumarède, "Négociants, voyageurs"; Desmet-Grégoire, Le Divan magique. 
Britain, ${ }^{5}$ and Portugal. ${ }^{6}$ As for Italy, there are studies on Naples ${ }^{7}$ and Sicily, ${ }^{8}$ which were ruled by Spain, and on the Republics of Venice ${ }^{9}$ and Genoa ${ }^{10}$ and the Grand Duchy of Tuscany, particularly Livorno. ${ }^{11}$ There is research on the Papal States, headed by Rome, ${ }^{12}$ and we can say the same for other areas of Europe such as Malta, ${ }^{13}$ Vienna, ${ }^{14}$ the Germanic territories, and Poland. ${ }^{15}$ I will discuss the Spanish case at length in the next three chapters.

Many Muslims traveled freely to different European ports and cities. Some were official ambassadors and envoys of their respective governments, usually escorted by a large retinue. Many more arrived by force of political events or personal misfortunes, especially those who came as slaves. But there were also many exiles, apostates who abandoned Islam for Christianity, and persons fleeing periodic famines in the Maghreb. A smaller but still significant group were tradesmen and sailors. And then there were the varied individuals who passed through or lived in European towns for many reasons - travelers, distinguished visitors, soldiers, servants, adventurers, and others. While it was once believed that they were chiefly transients or unwilling travelers (i.e., slaves), we now know that some of them stayed to reside permanently in Europe.

Most of these were slaves or captives, although the number of those declined from the mid-seventeenth century onward and they had disappeared by 180o. As successive peace treaties were signed by countries on both sides of the Mediterranean, only those who were prisoners of war remained.

5 Dakhlia, "Musulmans en France"; Matar, In the Lands of the Christians, "The Last Moors," and "The Toleration of Muslims"; D'Amico, The Moor in English Renaissance Drama.

Almeida Mendes, "Musulmans et moriscos du Portugal"; Matthee and Flores, Portugal, the Persian Gulf; Matthee, "Distant Allies"; Mendes Drumond Braga, Mouriscos e Cristãos; Lopes de Barros, A comuna muçulmana de Lisboa; Rosenberger, "Le Portugal et l'Islam Maghrebin." Varriale, "Tra il Mediterraneo"; Boccadamo, Napoli e l'Islam and "Liberi, manomessi, schiavi." Bonaffini, La Sicilia e i barbareschi, Sicilia e Tunisia, and La Sicilia e il mercato degli schiavi. Pedani, Venezia porta d'Oriente, esp. chaps. 8 and 19, and "Presenze islamiche a Venezia"; Lucchetta, "Note in torno a un elenco."

10 Oldrati, "Giovanni Antonio Menavino"; López de Coca Castañer, "Comerciantes genoveses"; Castagneto, "Consoli genovesi”; Fleet, European and Islamic Trade; Zaki, "Le Maroc et Gênes”; Pistarino, Genovesi d'Oriente; Heyd, Histoire du commerce du Levant.

11 Calafat and Santus, "Les avatars du 'Turc" "; Ghezzi, Livorno e il mondo islamico.

12 Caffiero, "Juifs et musulmans à Rome”; García-Hernán, "Persia en la acción del Papado"; Alonso, "A los orígenes de las relaciones."

13 Gugliuzzo, "Être esclave à Malte"; Brogini, Malte, frontière de Chrétienté and "L'esclavage au quotidien à Malte"; Fodor, "Piracy, Ransom, Slavery and Trade"; Wettinger, Slavery in the Islands of Malta and Gozo; Bono, "Malta e Venezia" and "Schiavi musulmani a Malta"; Fontenay, "L'esclave galérien" and "Chiourmes turques."

14 Do Paço, "Invisibles"; Sauer, Von Soliman zu Omofuma.

15 Schunka, "Türken taufen in Thüringen." 


\subsection{Muslims, a Minority among Slaves}

There is ample documentation throughout the Early Modern age of Muslim slaves in Central and Western Europe. ${ }^{16}$ S. Bono recently estimated their number at 2.525 million of all origins between 1500 and 1800 - most of those, about 2.250 million, between 1500 and 1649 . Their number declined significantly in the second half of the seventeenth century, leaving only about one hundred twenty-five thousand; it increased slightly in the eighteenth, however, to about one hundred fifty thousand. ${ }^{17} \mathrm{~A}$. Stella offers a figure of about two million slaves for Spain and Portugal over the same period, of whom three hundred to four hundred thousand would have been Muslims (North Africans and Turks). ${ }^{18}$ It is hard to assess these figures, which will always be subject to debate. ${ }^{19}$ If we accept Stella's then Bono's must be revised upward, giving a total of nearly three million slaves overall, of whom the Muslims would number five hundred to six hundred thousand.

Obviously Muslims did not make up the majority of slaves - most were from black Africa, having been brought directly from the Atlantic coast south of the Sahara. Of course we have to consider the sub-Saharan Africans who arrived in Europe after having been enslaved and Islamized in the Maghreb, but they were few in comparison to those who came by the Atlantic route (although some of the latter were also Muslim).

The religious, cultural, and ethnic identity of slaves differed greatly in the various European countries. In Portugal and Spain a majority were black Africans, which may have been the case in France and England also, especially in the capitals of Paris and London. But in Malta and most of Italy Muslim slaves far outnumbered those from black Africa.

There is no doubt that in Spain ${ }^{20}$ and Portugal ${ }^{21}$ the vast majority of slaves came from trade between the coasts south of the Sahara and the Iberian

16 Fiume, "La schiavitù"; Bono, Schiavi, "Schiavi in Europa," "Schiavi ottomano-maghrebini," and "Sklaven an der Mediterranen Welt"; Fontenay, "Pour un géographie de l'esclavage"; Stella and Vincent, "Europa, mercado de esclavos"; Marín and El-Hour, "Captives, children and conversion;" Moudine, "Le rachat des esclaves musulmans"; van Koningsveld, "Muslim Slaves and Captives”; Belhamisi, Les captifs algériens; Verlinden, L'Esclavage dans l'Europe médiévale I \& II.

17 Bono, Schiavi, 73-75.

18 Stella, Histoires d'esclaves, 78-79; Stella and Vincent, "Europa, mercado."

19 Vincent, "L'esclavage en Méditerranée Occidentale."

20 We deal with Spain in the appropriate chapter.

21 Almeida Mendes, Esclavages et traites modernes; Vincent, "Captivité, esclavage" and "Esclavage au Portugal"; Stella, Histoires d'esclaves; Lahon, Negro no coração do Imperio; Fonseca, Escravos e senhores and Os escravos em Evora; Saunders, A Social History of Black 
Peninsula, a system in existence from the second half of the fifteenth century. In the 15 oos the flow of slave labor shifted toward the American colonies settled by Spaniards and Portuguese, with the latter controlling most of the traffic in the sixteenth and seventeenth centuries. The Dutch, French, and English later joined the trade and eventually wrested commerce in slaves toward the aforementioned colonies from the Portuguese. ${ }^{22}$

In the Portuguese case, some Muslim slaves were captured in the course of chronic, mutual corsair activity, but most were taken when Portugal seized towns on the North African coast between Ceuta and Agadir. Portuguese enclaves there sent many military expeditions and raids into the interior that yielded a good number of slaves. But as indicated above, the nation directed its greatest effort to capturing slaves on the African coast south of the Sahara. ${ }^{23}$

For Italy we have monographs devoted to territories ruled by Spain such as Sicily, ${ }^{24}$ Naples, ${ }^{25}$ and Sardinia, ${ }^{26}$ as well as for the Grand Duchy of Tuscany - especially its port of Livorno, where the corsair Order of Saint Stephen was based. ${ }^{27}$ We also know of slaves in the Republics of Genoa ${ }^{28}$ and

Slaves and Historia social dos escravos; Vieira, Los escravos no arquipélago de Madeira; Ramos Tinhorão, Os negros em Portugal; Brasio, Os pretos em Portugal; Heleno, Os escravos em Portugal.

22 From the vast bibliography on the topic I will mention only Eltis and Engerman, The Cambridge World History of Slavery, vol. 2; Eltis and Richardson, Atlas of the Transatlantic Slave Trade; Heuman and Bumard, The Routledge History of Slavery; Klein, The Atlantic Slave Trade; Blackburn, The Making of New World Slavery; Eltis, "Trade between Western Africa and the Atlantic World" and Economic Growth and the Ending of the Transatlantic Slave Trade.

23 Rodriguez da Silva Tavim, "Educating the Infidels Within"; Vincent, "Esclavage au Portugal"; Rosenberger, "Mouriscos e elches."

24 Messana, "La 'resistenza' musulmana"; Bonaffini, La Sicilia e il mercato degli schiavi; Bono, "Ribellione e fuga"; Aymard, "De la traite aux chiourmes"; Motta, "La schiavitù a Messina"; Marrone, La schiavitù nella società siciliana; Avolio, La schiavitù domestica in Sicilia; González-Raymond, La Croix et le Croissant and "Les esclaves maures et l'Inquisition"; Fiume, Il santo patrono e la città; Fiume and Modica, San Benedetto il Moro.

25 Vincent, "Les esclaves des galères napolitaines"; Boccadamo, Napoli e l'Islam and "Liberi, manomessi, schiavi"; Varriale, "Conversioni all'ombra del Vesuvio" and "Tra il Mediterraneo e il fonte"; Carnevale, "Il corpo dell'altro"; Palmieri, "I turchi."

26 Carboni, L'umanità negata; Plaisant, "Un censimento di schiavi a Cagliari”; GonzálezRaymond, La Croix et le Croissant and "Les esclaves maures et l'Inquisition."

27 Santus, "Moreschi in Toscana" and "Il turco e l'inquisitore"; Calafat and Santus, "Les avatars des 'Turcs'”; Angiolini, "Slaves and Slavery in Early Modern Tuscany" and I cavalieri e il principe; Origo, "The Domestic Enemy"; Bono, "Livorno e la schiavitù"; Ciano, "Gli schiavi ed i forzati”; Frattarelli Fischer, "La schiavitù a Livorno"; Salvadorini, "Traffici con i paesi islamici."

28 Lucchini, La merce umana; Bono, "Schiavi Musulmani a Genova"; Gioffre, Il mercato degli schiavi a Genova; Tria, La schiavitù a Liguria. 
Venice, ${ }^{29}$ as well as in Rome - the capital of Christendom ${ }^{30}$ - and some of the Papal States such as Bologna. ${ }^{31}$ And finally, there are studies on slaves in the cities of Bari, Turin, Ferrara, and Mantua. ${ }^{32}$

There were also Muslims slaves in Northern and Central Europe, though in much smaller numbers. ${ }^{33}$ We have cases from the Low Countries, such as the Dutch capture of 132 men from Salé in 1636; they were subsequently sold as slaves. ${ }^{34}$ There are also notices from Great Britain, ${ }^{35}$ the Austro-Hungarian Empire, ${ }^{36}$ Germany, ${ }^{37}$ and Poland. ${ }^{38}$

Malta was unquestionably the great slave market of the Early Modern age. The growing number of captured slaves there was spurred by the establishment of the Order of Saint John of Jerusalem on the island in 1530, and the burgeoning number of their galleys that patrolled the coasts of Muslim lands, especially in the Maghreb. Between 1548 and 1576 the number of slaves on the island remained at about four hundred, but by 1582 it had risen to eight hundred, in 159 o to 1,405 , in 1599 to sixteen hundred, in 1632 to 1,846 , and in 1669 to 2,19o. In 1700 about three thousand were registered, a number that dropped to 2,500 between 1741 and 1769 . When the French conquered the island in 1798 they found about two thousand captive Muslims. ${ }^{39}$ Muslims as a whole - North Africans and Turks - always made up the largest contingent of slaves: their proportion varied between forty and eighty percent, with the latter figure being most common throughout the Early Modern period. There was also a certain

29 Ricci, "Les derniers esclaves domestiques”; Tenenti, “Gli schiavi di Venezia”; Lazzari, "Del traffico."

3o Hanb, "Gefangen und versklavt"; Nepi, "The Restitutiones ad libertatem"; Caffiero, "Juifs et musulmans à Rome"; Miege, "Captifs marocains en Italie"; Meredith-Owens, "Traces of a Lost Autobiographical Work"; Bertolotti, "La schiavitù pubblica e privata."

31 Sarti, "Bolognesi schiavi dei 'turchi'"

32 For Bari see Massa, "La schiavitù in terra di Bari"; for Turin, Cerutti, Étrangers, esp. chap. 2; for Ferrara and Mantua, Ricci, "Les derniers esclaves domestiques."

33 For an overview see Bono, "Schiavi europei e musulmani."

34 Caillé, "Ambassades et missions marocaines aux Pays-Bas," 59-6o. For the eighteenth century see Boogert, "Redress for Ottoman Victims."

35 Shyllon, Black Slaves in Britain.

36 Do Paço, "Invisibles dans la banalité?"; Sauer, Von Soliman zu Omofuma; AlexandrescuDersca, "La Condition des captifs turcs."

37 Schunka, "Türken taufen"; Kreutel and Spies, Leben und Abenteuer; Osman and Kreutel, Zwischen Paschas und Generälen.

38 A Turk, Kasra Musa, was a slave or prisoner in Poland for thirty years before being freed in 1552: Dziubinski, "Un ancien esclave turc."

39 Brogini, Malte frontière de Chrétienté, 658-59. For French purchases of slaves in Malta in the eighteenth century see Labat Saint Vincent, "Achats et rachats." Fontenay, "Il mercato maltese degli schiavi." 
number of enslaved Jews in Malta, while blacks - subjects of Maghrebi states or members of tribal groups - were always in the minority.

The vast majority of these slaves belonged to the Order and spent their lives rowing in the galleys, laboring in the shipyard, and fortifying Birgu, Valetta, Sanglea, and the Slaves' Prison. Their harsh lives produced revolts in 1531 and 1596 and a plot in 1749, all of them swiftly crushed. Most held tightly to their beliefs and organized a prayer area inside the prison, but others accepted baptism, whether from conviction or a from wish to improve their living conditions. There are documented cases of both male and female slaves who married Maltese residents. There were also many who achieved their freedom through a variety of means. Between 1686 and 1706757 safe-conducts were granted that allowed their bearers to return to their countries of origin. ${ }^{40}$

The extent of Muslim slavery in France should make us reconsider the true nature of the alliance between the "Most Christian King" Francis I and the Ottoman Empire, which resulted in the signed capitulations of 1536 and their later renewals. We could say the same of the many French peace treaties with Maghrebi countries, though most of them were meant to ensure the mutual ransoming or exchange of slaves. We have little notice of Muslim slaves in France before the mid-seventeenth century ${ }^{41}$ but from that time onward their presence increases. The king manumitted a group of slaves in 1669 on the occasion of an embassy from the Ottomans. ${ }^{42}$ At around that time there was a pressing need for enough slaves to man the galleys: one ship's complement was a chiourme, of which about a third normally consisted of Muslims. In 1670 Louis XIV's envoy to Istanbul, who believed that both countries would have to free their slaves, estimated that the galleys of France held two thousand Turks, who formed the best of the crews. In the twenty-six years between 1682 and 1707 5,594 Muslim rowers were registered: there were about 1,026 in 1682, and between 1685 and 1687 their number rose to at least 2,040. In the the eighteenth

40 Gugliuzzo, "Être esclave à Malte"; Wettinger, "Esclaves noirs à Malte," Slavery in the Islands of Malta and Gozo, and "Coron Captives in Malta"; Bono, "Malta e Venezia" and "Schiavi musulmani a Malta"; Brogini, "Une activité sous contrôle" and "L'esclavage au quotidien à Malte”; Depasquale, "Quelques aspects de l'esclavage”; Fodor, "Piracy, Ransom”; Fontenay, "L'esclave galérien" and "Chiourmes turques"; Cassar, "A Medical Service for Slaves."

41 In 1505 a Moorish slave, Clémence, was set free. In the first half of the seventeenth century Marie de Médicis received two slaves as gifts: Mathorez, "Les éléments de population orientale," esp. 179, 199.

42 After that there are few data about Muslim slaves in France. In 1718 the Dey of Algiers demanded the freeing of nine slaves held in Marseille: Poumarède, "Négociants, voyageurs"; Mathorez, "Les éléments de population”; Berbrugger, "De l'esclavage musulman." 
century the count of Muslim slaves fell drastically ${ }^{43}$ but they were still present until its final third, according to a few isolated notices. ${ }^{44}$

During preparations for the embassy of Mehmed Effendi to Paris in 1720, the sultan asked that five hundred Muslim slaves be freed; the French ambassador, Bonnac, bargained to reduce the number to "a hundred, [or] a hundred and fifty." Mehmed, who was interested in particular individuals enslaved in the galleys in Marseille, put the issue to Maréchal Villeroy in these terms:

You claim to be the best friends of the Most Exalted Empire, [yet] you keep more than a thousand of the brethren of my Faith as slaves and in prison; you make them ply the oars in your galleys; what are their crimes? Why are they held in this slavery?45

The maréchal did not deny the existence of Muslim galley slaves, though he alleged that they enjoyed a certain freedom of movement. ${ }^{46}$

The falling number of Muslim slaves in France was matched in general terms by the rising number of sub-Saharan Africans. ${ }^{47}$

Enslavement of Muslims obviously occurred in countries or states that were enemies of the Muslims throughout the Early Modern age, like Spain, Portugal, Malta, and some Italian territories. Their mutual hostility made it a logical outcome. But we find it also in states that signed capitulations and treaties with the Ottoman Empire and North African powers - treaties that in theory should have ended slavery on both sides. Such was the case for France, England, and certain Central European states, as well as the Grand Duchy of Tuscany whose

43 Poumarède claims that between 1689 and 1693 over 1,250 slaves were registered in France, and he also notes the mercantile activity of Turkish galley slaves: "Négociants, voyageurs." Labat Saint Vincent, "Achats et rachats"; Boyer, "La chiourme turque"; Fournier, "Un marché de Turcs"; Mathiex, "Levant, Barbarie et Europe chrétienne."

44 In $175^{\circ}$ eight men from Crete were sent to the French galleys: Poumarède, "Négociants, voyageurs." Labat Saint Vincent, "Achats et rachats"; Desmet-Grégoire, Le Divan magique, 34-35; Boyer, "La chiourme"; Fournier, "Un marché de Turcs."

45 "Vous prétendez être les meilleurs amis du Très Haute Empire, vous retenez plus de mille de mes frères en ma Loi esclaves et en prison; vous leur faites tirer la rame sur vos galères; quels sont leurs crimes? Pour quelle raison les detener dans cet esclavage?": Mehmed Effendi, Le Paradis del infidèles, 144.

46 Mehmed explained his request: "I had decided to ask the minister, in the good climate that reigned between our two empires, for what crime the Turkish slaves in France had been enslaved": Mehmed Effendi, Le Paradis des infidels, 25, 142-47; quotations at 142-43. Koufinkana, Les esclaves Noirs en France; Boulle, Race et esclavage dans la France. 
port, Livorno, received Muslim merchants and ships while maintaining the Order of Saint Stephen, which specialized in seizing Muslim prizes. ${ }^{48}$

In Mediterranean nations Muslims rowed in the galleys until those ships lost their usefulness in the early decades of the eighteenth century. They were also assigned to hard labor on a broad array of public works such as shipyards, mines, agriculture, roads, and fortifications; therefore we find large bagnios or holding places for prisoners in some cities. ${ }^{49}$ During their long stays in port cities such as Toulon, Marseille, Naples, Valetta, and Cartagena, many galley slaves found work on their own or by contracting with domestic servants or porters; they set up stands where they sold coffee, liquor, and other products. ${ }^{50}$ Some were owned by private individuals, but the conditions of their lives were harsh; ${ }^{51}$ that fact, beside the slaves' natural desire to gain their freedom, explains the slave revolts in Malta in 1531,1596 and 1749 and in Trapani in $1755^{.52}$

Slaves were able to establish some limited contact with Christians, especially those with whom they shared similar living conditions, a fact that in practice breached the rigid frontier that separated Islam from Christendom in the Early Modern period. On the rowing benches, in prisons and holding pens, in certain neighborhoods in port, in some private houses, in workshops, and in the fields, interaction between Muslims and Christians was the order of the day. ${ }^{53}$ But mistrust and bad faith, even open hostility, were just as frequent. ${ }^{54}$ Members

48 Atti del Convegno L'Ordine di Santo Steffano; Angioloni, I Cavalieri e il Principe.

49 There are many references to Turks in the French galleys in Zysberg, Les galériens.

50 When the Ottoman ambassador to France in 1720 , Mehmet Effendi, asked about galley slaves in Marseille Maréchal Villeroy assured him that they were not held in prison but were at liberty and "sold things around town ... they do not care about gaining their freedom. Each of them amasses a sum of money through trade, and if we sent them away they would not want to leave" ("[ils] trafiquaient en ville ... [ils] ne se soucient point d'avoir leur liberté. Chacun d'eux amasse un certain fonds en trafiquant, et si nous les chassions ils ne voudraient pas s'en aller"): Mehmed Effendi, Le Paradis des infidèles, 142-47. See also Desmet-Grégoire, Le Divan magique, ${ }_{36-39}$. Muslim galley slaves in Marseille set up stalls where they sold coffee and liquor or hired themselves out as domestic servants: Zysberg, Les galériens, ${ }^{145}-51$.

51 Sarti, "Tramonto de schiavitù" and "Viaggiatrici per forza"; Bono, Schiavi musulmani nell'Italia Moderna, "Schiavi musulmani sulle galere," and "Capture di musulmani"; Livi, La schiavitù domestica.

$5^{2}$ A harsh but not very convincing picture of the slaves' conditions is in Belhammisi, Les captifs algériens. He modified it later in "Course et contre-course en Méditerranée."

53 We do not mean to paint an idyllic picture of harmonious living; there was always mistrust and hostility between the two groups.

54 In Marseille in 1704 a wave of robberies and violent crimes was blamed chiefly on the Turks: Zysberg, Les galériens, 162-70. 
of an Algerian delegation to Marseille in 1620 were massacred, while a series of attacks and robberies in that same city in 1704 was blamed on Muslim slaves. ${ }^{55}$

We are beginning to have more detailed information about places of worship, whether official or unofficial, but wherever a certain number of Muslims congregated they found a place in which to practice their religion. The muezzin's call to prayer issued from the mosque in Naples in the sixteenth century: "He placed his finger by his ear and said a Moorish expression that in Italian means 'God be praised,' and in this manner he called the Moors to the mosque to pray according to their custom." ${ }^{56}$ There was also a space for prayer in the Slaves' Prison in Malta, in Marseille, Toulon, ${ }^{57}$ and a similar one in the shipyard at Cartagena at the end of the eighteenth century. ${ }^{58}$

We know little about burying grounds for Muslims who died in Europe, aside from studies of cemeteries in Marseille and Toulon ${ }^{59}$ and burial sites in Venice, ${ }^{60}$ Naples, ${ }^{61}$ and Cartagena.

Rulers in both the Maghreb and Western and Central European countries that bordered the Mediterranean maintained a sort of entente to guarantee a more-or-less humane treatment of captives; some religious freedom was also permitted on both shores, though it was much more limited for Muslims in Europe. By that means, complaints by Christian slaves in North Africa and Muslim ones in Europe did not set off a chain of reprisals against slaves held by the other side; ${ }^{62} \mathrm{~W}$. Kaiser has called it "reciprocity as a principle of security."63 In 1707 a Turkish galley slave who kept a shop bought some liturgical objects that had been stolen from a church in Marseille; on being found out he was accused of theft and sacrilege and condemned to death. He managed to get a letter about his case to Istanbul, on which the Ottomans made clear to the French that if the Turk was executed they would take revenge on the French slaves they held. ${ }^{64}$

55 On the "massacre of the Turks" in 1620 see Kaiser's interpretation, "Asymétries méditerranéennes," 429-40; for 1704 see Desmet-Gregoire, Le Divan magique, 38-39.

56 "Si meteva il dito a l'orechia et diciva una parola moresca, che in lingua italiana vuol dire Dio sia lodato, et in questo modo convocava li mori a la moschea afar oratione ad usanza loro": Varriale, "Tra il Mediterraneo."

For Malta see Gugliuzzo, "Être esclave à Malte"; for France, Desmet-Grégoire, Le Divan magique, and Boyer, "La chiourme turque."

58 For Cartagena (on which more below) see Barrio Gozalo, Esclavos, 137-225.

59 Bertran, "Les cimetières"; Joseph, "Le cimetière des forçats."

6o Lucchetta, "Note intorno a un elenco."

61 Varriale, "Conversioni"; Carnevale, "Il corpo dell'altro."

62 Bono, "Schiavi maghrebini in Italia."

63 "Réciprocité comme principe sécurisant”: Kaiser, “Asymétries méditerranéennes."

64 Desmet-Grégoire, Le Divan magique, 39-40. 
Muslim slaves also had opportunities to gain their freedom, and everything indicates that ransom was the commonest method. ${ }^{65}$ We know what great efforts Muslim authorities made to ransom their coreligionists captured at the Battle of Lepanto. ${ }^{66}$ Some Moroccan sultans, like Ahmad al-Mansur, took a great interest in ransoming certain of their subjects, ${ }^{67}$ but in the sixteenth and seventeenth centuries it was merchants who negotiated most ransoms: they rescued tens of Muslims from Malta from the end of the sixteenth century through the seventeenth, ${ }^{68}$ and also from Sicily. ${ }^{69}$

For the eighteenth century we have richer stores of documents, and monographs that have cast light on the important role played by Ottoman and Maghrebi ambassadors and envoys in gaining freedom for members of their faith..$^{70}$ The best-known case is the dedication of Sultan Muhammad b. Abdallah of Morocco, who in the second half of the eighteenth century managed to ransom or exchange all the Moroccan captives in Spain, as well as many Turkish, Algerian, Tunisian, and Tripolitan slaves in that country and six hundred Muslims in Malta. ${ }^{71}$

An undetermined number, which historians think was small, gained their freedom through the generosity of their owners or in exchanges of slaves, but many more bought their liberty with earnings from their own labor. ${ }^{72}$

If Muslim slaves in Europe contributed in even a limited way to communication between the two shores of the Mediterranean, it is logical to assume that their role was largest in Spain, Italy, Portugal, and Malta, the areas where

65 Bono, "Riscatto di schiavi”; Boubaker, "Réseaux et techniques de rachat."

66 Rosi, "Alcuni documenti" and "Nuovi documenti."

67 Ahmad b. al-Qâdi, a captive in Malta and southern Spain in 1586-87, was ransomed by Sultan Ahmad al-Mansur for twenty thousand escudos: Loukili, "D'une captivité musulmane."

68 Fodor, "Piracy, Ransom, Slavery."

69 Brogini, Malte, 358-64, 6o3-14; Boubaker, La Régence de Tunis, 167-76.

70 Ginio, "Piracy and Redemption." For Mehmed Effendi in France in 1721 see Mehmed Effendi, Le Paradis des infidèles, 25, 142-47. On Moroccan ambassadors to Spain see below, chaps. 4 and 6.

71 Mouline, "Un ambassadeur rédemptoriste"; Ben Driss, "L'impegno umanitario del sultano"; Lourido Díaz, Marruecos, 41-84, and "La obra redentora del sultán”; Arribas Palau, "Un rescate" and "El marroquí Muhammad b. 'Abd al-Hadi." There were also ransoms for individuals such as Lalla Fatma bint Muhammad b. Abd al-Rahman al-Sharif, who was a captive in Malta together with her husband and a servant in the 179os and wrote twice to Muley Sliman asking for their freedom: Loukili, "D'une captivité musulmane."

72 For the Italian case in particular see Bono, Schiavi musulmani, 383-46o; Nepi, "The Restitutiones ad libertatem"; Fodor, "Piracy, Ransom." 
their numbers were greatest. Where they were few, in Northern and Central Europe, their influence was smaller.

\subsection{Hundreds of Muslim Embassies}

During the Early Modern period the Ottoman Empire, the North African Regencies, and Morocco had no permanent official representation in Central and Western Europe. The Sublime Porte demanded for its merchants in Christian lands the same protections that Westerners enjoyed under the Ottomans, but the requirement seems to have been limited to Venice and the borderlands of the Hapsburg Empire. ${ }^{73}$ Permanent representations in the form of embassies and consulates, however, did not appear until the late eighteenth century. Before that there were only a few trade representatives in a largely unofficial capacity. In contrast, European kingdoms, republics, and cities maintained many consulates general, consulates, and vice consulates in the Ottoman Levant and the Maghreb throughout the Early Modern age. ${ }^{74}$

Muslims rulers sent a large number of ambassadors and envoys - certainly more than three hundred - to Europe..$^{75}$ Although it may seem somewhat tedious to list them, even if not exhaustively, we must offer some sense of the weight that they represented. The Ottoman Empire sent many ambassadors to European countries: over one hundred to Venice from the sixteenth to the eighteenth centuries, almost half of them between 1500 and $1550 .{ }^{76}$ France received more than thirty in the same period: in the first two centuries, at least in $1533,1534,1565,1571,1581,1583,1597,1601,1607,1609,1618-1619,1652$, and 1669. The eighteenth century saw delegations by Mehmed Effendi, the first with the official title of "ambassador" (1720-1721), his son Said Effendi (1741-1742), Ali Effendi (1797), Muhid Effendi, and Halet Effendi, who witnessed Napoleon's coronation in $1804 .{ }^{77}$ The best-known embassy is that of Mehmed Effendi,

\footnotetext{
73 Kaiser, "Asymétries," 419; Pedani, "Consoli veneciani."

74 Ulbert, "Bibliographie."

75 I will not be concerned here with the many embassies led by Europeans or Jewish subjects of the various Muslim states.

76 A total of 176 between 1384 and 1762: Pedani, In nome di Gran Signore, "Ottoman Envoys to Venice," and "Ottoman Diplomats in the West." In the first half of the sixteenth century the Porte sent an ambassador to Venice almost every year, and nine Persian ambassadors arrived there between 16oo and 1639. Ambassador Ali Bey, in 1514, brought an escort of eighty persons: Valensi, Ces étranges familiers, 195, 198.

77 These included the embassies of Mahmûd (1581), Hasam Agha and Ali Mütereferrika (1583), Mustafa Agha (16o1), Hüseyn Agha (1618-19) and Suleyman Aga (1669): Valensi, Ces étrangersfamiliers, 193, 195-96, 286-87; Poumarède, "Soldats et envoyés"; Desmet-Gregoire,
} 
who left an interesting account of Paris as the "Paradise of the infidels" at that time..$^{78}$ The Sultan also sent delegations to London, ${ }^{79}$ Vienna, ${ }^{80}$ Berlin, ${ }^{81}$ Florence, Ferrara, and other European cities. ${ }^{82}$ But only at the end of the eighteenth century did the Ottoman Empire decide to open permanent embassies in London (1792), Berlin (1794), Vienna (1796), and Paris (1796). ${ }^{83}$

The sultans of Morocco sent about a dozen ambassadors and envoys to France. The first was the Morisco Ahmad Ibn Qasim al-Hajari (1611-1614), followed by other representatives in 1612-1613, 1619, 1681-1682, 1685, 1698-1699, 1759, 1772-1773, 1774-1775, 1777-1778, 1781, 1786, and 1807. ${ }^{84}$ London received more than twenty embassies: in 1588-1589, 1595, 16oo-16o1, 1628, 1637-1638, 1638, 1657, 1681, 1685, 1700 (two), 1706-1708, 1723, 1725, 1737, 1762, 1766, 1773, and $1781 .{ }^{85}$ Several Moroccan ambassadors and envoys arrived in The Hague,

Le Divan magique, 18-25; Mehmed Effendi, Le Paradis des infidèles (notes by Veinstein, 22-26); Herbette, Une ambassade ottomane.

78 Guarisco, “Un ambassadeur ottoman”; Mehmed Effendi, Le Paradis.

79 One in 1583: Valensi, Ces étrangers, 292. Mahmoud Raïf led an embassy from 1793 to 1796: Mehmed Effendi, Le Paradis, 242-48. Brotton,The Sultan and the Queen.

8o Kara Mehmed Pacha was sent in 1665 and Ibrahim Pacha in 1719: Mehmed Effendi, Le Paradis, 16, 22.

81 More than two hundred people formed the delegation of Achmet Effendi: Valensi, Ces étrangers, 199, 286.

82 To Ferrara in $155^{8}$ and Florence in 1593: Pedani, In nome, 192.

83 Bacqué-Grammont et al., Représentants permanents.

84 Their names were Ahmed El-Guezouli (1612-13), Sidi Farès (1619), Hadj Mohamed Temim (1681-82 and 1685), Abdallah ben Aicha (1698-99), Hadj Tahar Medout (1759), Ali Pérès (1772-73 and 1781), Abdallah Escalante (1774-75), Tahar Fennich (1777-78), Hadj Larbi Moreno (1786), and Hadj Driss Errami (1807). Matar, Europe through Arab Eyes, 72-106; Penz, Une ambassade marocaine and Les emerveillements parisiens; Caillé, "Les naufragés" and "Ambassades et missions marocaines en France." Also useful, though it concerns a later period (1845-46), is the memoir Une ambassade marocaine chez Louis-Philippe.

85 They were led respectively by Merzouk Ahmed Benkacem (1588-89), caid Ahmed ben Adel (1595), Abdeluaheb ben Messud Anun (160o-01), Pasha Ahmed Benadellah (1628), Jawdar Ben Abdellah (1637-38), caid Mohamed Benaskar (1638), Abdelkrim Annaksis (1657), Mohammad Ben Haddu Attar (1681), Abdallah ben Aisha (1685), Mohammad Cardenas (1700), Haj Ali Saban (1700), Ahmed ben Ahmed Cardenas or Ahmed Qardansh (1706o8), Abdelkader Perez (1723 and 1737), Mohammad ben Ali Abgali (1725), Abdelkader Adiel (1762), Admiral el-Arbei ben Abdellah ben Abu Yahya al-Mestiri (1766), Sidi Taher ben Abdelhaq Fennish (1773), and Mas'ud de la Mar (1781). We should also mention the envoys from the corsair republic of Salé, Mohammed Bensaid and Ahmed Narvaez (1627) and Mohammed Clafishou (1629). Brown, "Anglo-Moroccan Relations." Twenty persons formed the delegation of Mohammad Ben Ali Aggali: Valensi, Ces étrangers, 197-98, 292. La Gazeta of Madrid reported on a number of these embassies, like those of El Harbi Misteri to London (1767) and Fennish (1772-73): Gazeta de Madrid, 24-31 May 1767; 22 June $1767 ; 24$ September 1772. 
capital of the Low Countries: in 16o9-1610, 1610-1611, 1611-1614, 1612-1613, 1624$1625,1629,1645,1659$, and $1770 .{ }^{86}$ Moroccan representatives were also sent to Vienna (1783), ${ }^{87}$ Malta, ${ }^{88}$ Naples, ${ }^{89}$ and Cagliari (1786 and 1792). ${ }^{90}$ In almost every case the motive was the ransoming of slaves or an attempt to ensure the peace after a serious confrontation at sea. ${ }^{91}$

The Regency of Algiers, for its part, sent twenty-eight delegations to Western Europe, most of them to the court in Paris. ${ }^{92}$ The most dramatic proved to be the embassy of 1620, during which about fifty Muslims, most of them members of the delegation, were slaughtered. The incident ("the massacre of the Turks") was perpetrated by an angry mob as the embassy passed through Marseille: it was rumored that an Algerian captain had killed the whole crew of a French ship. ${ }^{93}$ Algiers also sent diplomatic representatives to the courts in London ${ }^{94}$ and the United Provinces..$^{95}$

The Regency of Tunis sent at least twenty-four ambassadors to France between 1616 and 1825. In the seventeenth century they traveled in 1616-1617, 166o, 1666, 1681-1683, and 1689-169o; in the eighteenth they did so in 1716-1717,

86 The ambassadors were Hammou Ben Bachir (1609-10), Ahmed Ben Abdallah with an escort of five persons (1610-11), the aforementioned Morisco Ahmad Ibn Qasim, who combined the journey to the Netherlands with his mission to France (1611-14), Ahmed el-Guezouli with four companions (1612-13), Youssef Biscaino with five (1624-25), the Morisco Mohamed Vanegas, also with five (1629), and Mohammed Ben Askar (1645). The triple embassy of Brahim Duque, Mohammed Penalosa, and Brahim Manino (1659) had an unknown number of members, but one of them was a woman; finally Hadgi Mehemet Resini (1770): Caillé, "Ambassades et missions marocaines aux Pays-Bas"; Valensi, Ces étrangers, 197, 292; Gazeta de Madrid, 18 September 1770.

87 Caillé, "Un ambassade marocaine."

88 Mouline, "Un ambassadeur rédemptoriste”; Arribas Palau, "Rescate de cautivos," "El marroquí Muhammad b. 'Abd al-Hadi," and "Un rescate de 6oo cautivos."

89 Arribas Palau, "El sultán de Marruecos envía un regalo."

90 Pinna, "Riscatto di schiavi."

91 Caillé, Les accords internationaux.

92 Among them those of Morat Raiis (1567), Ali Pinchinin (1576-77), 1620, Hamza (1628), two in 1684 (one with a train of twelve persons), and Mehemet Elemin (169o-91): Valensi, Ces étrangers, 195, 197-98; Poumarède, "Soldats et envoyés," 426-27.

93 In the riot two of the Regency's interpreters or chaoux, Caynam or Quenan Agha and Rozan Bey, were murdered along with ten ship's captains and about forty captives who were being held in two buildings. Another fifteen managed to escape, as did seven or eight other Muslims who were elsewhere in Marseille at the time: Kaiser, "Asymétries"; Pillorget, "Un incident diplomatique" and "Histoire du massacre des Turcs," 191-93; Grammont, Histoire du massacre des Turcs.

94 Matar, Europe through Arab Eyes, 72-106; for the 1625 embassy see Valensi, Ces étrangers, 292.

Valensi, Ces étrangers familiers, 195. 
1727-1729, 1734, 1743, 1771, 1777, 1797, 1802, and $1825 \cdot{ }^{96}$ Tunis sent ambassadors to other courts as well, including to Vienna in $173^{2}$. Yussouf Khodja was dispatched to London (1721) and later to Naples (1732-1733). ${ }^{97}$

Tripoli dispatched several delegations as well, especially to France and England. ${ }^{98}$ The Mamluk rulers of Egypt likewise directed embassies to Europe before they were overcome by the Ottoman conquest in $1517 .{ }^{99}$ Seyyed Mobarak (Asic Mobarac or Mombareca in contemporary sources) was the king or sheikh of Ahwaz ("Oeza" or "Ueza" in Spanish documents), a kingdom in the Persian Gulf area northeast of Basra between the Ottoman and Persian empires; he dispatched a delegation that arrived in Naples in July 1617. It consisted of a Portuguese and a certain "Sheikh Ferhan, one of our most notable Christians and our ambassador," and was charged with negotiating an alliance against the Turks - specifically, for the military conquest of Basra and Bahrain. Its members reached Madrid on 3 October, but their efforts bore no fruit. ${ }^{100}$

In the first half of the seventeenth century in particular, when both Europe and Persia hoped for a mutual alliance against the Ottoman Empire, the Safavids sent many embassies to different countries. The Republic of Venice received nine of these between 1600 and 1639, among them one led by Muhammad Emin Beg and Fethi Beg in 1603. ${ }^{101}$ It was common for these delegations to visit other European courts as well as the city of Venice. In 1599 Ambassador Hussein Ali Beg (Cussein Alibey) left Persia accompanied by the famous Englishman Anthony Sherley. Their retinue included four gentlemen: Ali Quli (the ambassador's nephew), Uruch Beg, Hasan Ali Beg, and Bunyad Beg, as

96 The ambassadors were Baba Drevis, Dérouiche (1616-17), Baba Ramadan (166o, 1666, and 1681-83; he complained about the treatment he received and his hosts in turn complained of his conduct), Mehemet Bouloukbachi and Hadj Ali Chaouch (1689-9o, involving new complaints), Ahmed Khodja and Ahmed (1727-29), Ahmed Agha and Hadj Abadalla Agha (1734), Ali Agha and Mehemed Khodja (1743), Ibrahim Khodja (1771), Suleiman Agha (1777), Mohamed Khodja (1797), Mustapha Arnaout (1802), and Sid Mahmoud Kahia (1825). Matar, Europe through Arab Eyes, 72-106, and "La France vue par des ambassadeurs"; Newman, "Tunisian Diplomatic Representation"; Demerseman, "Une mission tunisienne"; Pellegrin, "Notes d'histoire tunisienne"; Hugon, "Une ambassade tunisienne." Matar, Europe through Arab Eyes, 72-106; Matar, "La France vue par les ambassadeurs"; Newman, "Tunisian Diplomatic Representation"; Demerseman, "Une mission tunisienne"; Pellegrin, "Notes d'histoire tunisiennes"; Hugo, "Une ambassade tunisienne."

97 Fendri, "Yûsuf Khûja chez le Prince Eugène."

98 In 1687, 1704, and 1775, the last led by Sidi Abdurrahman Bediry: Valensi, Ces étrangers, 292; Desmet-Grégoire, Le Divan magique, 18-25.

99 Wansbrough, "A Mamluk Ambassador."

100 Gil Fernández, El imperio luso-español, 2:417-21.

101 Valensi, Ces étrangers, 195, 287; Zekiyan, "Xoga Safar ambasciatore." 
well as fifteen servants, among them a faqih named Amir. Hussein bore letters from the Shah to the Duke of Muscovy, King Sigismund III Vasa of Poland, Emperor Rudolf II of Germany, the Queen of England, the monarchs of Scotland, France, and Spain, the lords of Venice, and the Pope. In exchange for an alliance against the Turks the Shah was offering them friendship, an exchange of ambassadors, the establishment of permanent Christian embassies in Persia, and freedom for Christians in his lands to practice their religion both in public and in private. The delegation reached Moscow in December 1599, and in October 160o Rudolf II was their host in Prague. Because an Ottoman ambassador was already present in Venice as they approached, they avoided tensions by bypassing that city. They entered Florence in March 1601 and were welcomed by the Duke at Pisa; by April they were in Rome. The Englishman left them before they set out toward Spain in July 1601. By then they were reduced to a mere "ten or twelve Moors," since their secretary, barber, and cook had stayed in Rome to convert to Christianity under the Pope's protection. The whole delegation, in fact, had already shrunk after four servants had returned to Persia from Moscow. Hussein and Sherley had quarreled, since each of them considered himself the sole ambassador, and in the end they parted company. By the time they reached Spain only the Persian was in sole command; we shall describe the mission further in Chapter $4 .{ }^{102}$

In that same year of 1600 Shah Abbas sent Assad Beg, disguised as a merchant, to Europe to learn what had become of Hussein Ali Beg's embassy; on finding no news he decided to return to Persia but died while crossing Turkish territory. Later, in 1604, Bastam Qoli Beg and his secretary Diego Miranda led a second mission to Rome from the Shah, but Bastam perished on the way to Lisbon, while Miranda, who replaced him, died tragically in Valladolid. Shah Abbas, disturbed by the lack of news from them, sent three new envoys to Europe in 1604: Zain-ul-'Abidin Beg, Zejnel Khan Shamlu, and Mehdi Quili Beg. The three were at Rudolf II's court in Prague in 1605, and one of them reached France and was received by the king. ${ }^{103}$

In 1607 Ali Qoli Beg was in Tsaritsyn as a Persian ambassador on his way to Rome. Zain-ul-'Abidin Beg led another embassy from the Shah in 1608, visiting Holland, Flanders, and France; he sailed for home from Marseille in September of that year. ${ }^{104}$ Also in 1608 the Shah sent a delegation similar to that of 1599

\footnotetext{
102 Gil Fernández, El imperio luso-español, 1:79 ff.; Alonso, "Embajadores de Persia"; Davies, Elizabethans Errant; Penrose, The Sherleian Odyssey; Ross, Sir Anthony Sherley.

103 Shah Abbas sent Assad Beg to Venice in 1600 for news of Hussein and Sherley's embassy, but he returned empty-handed to Persia: Gil Fernández, El imperio, 2:40-44, 79, 107-08, 174, 186-87, 19o, 571-72; Persia, Relaciones de Don Juan de Persia, 245-6o.

104 Gil Fernández, El imperio, 2:49.
} 
that visited the courts of Poland, Prague, the Grand Duchy of Tuscany, the Papal States, England, and Spain; its co-leaders were Robert Sherley, brother of Anthony, and the Persian Denguis Beg. The latter was executed by the Shah on his return home in $1613 .{ }^{105}$

Two more Persian ambassadors, Çinal Cambreque and Azambeque, were sent to France in 1608 and embarked on their return journey in Lisbon at the end of that year. ${ }^{106}$ In September 1609 Ali Qoli Beg's delegation arrived in Rome (the Shah called him "one of my confidants whom I usually send with such embassies") accompanied by Francisco de Acosta, with letters for the Pope and Philip III. ${ }^{107}$ Musa Beg was in Holland in 1625, while Naqd Ali Beg went to England in $1626 .{ }^{108}$ All these embassies were attempts to form a common front between Persia and the European powers against the Ottoman Empire, but they produced no detectable results. Still, there was one more to Louis XIV in France and another led by Mohammed Reza Beg in $1715 .{ }^{109}$

Little is known about how the consular networks of the Ottoman Empire and the Maghrebi countries appeared and were consolidated in Europe. It happened at a late date, as is confirmed by a recent bibliographic inventory of consulates from their origins to World War I, which lists 3,305 monographs. Only thirty-seven refer to Muslim countries: there are thirteen for the Ottoman Empire, twelve for Tunis, two for Morocco, and ten for Persia, ${ }^{110}$ and most of those references are not to the creation of consulates from Muslim countries in Christian Europe but to the delegations that we have been describing in the preceding pages.

A few Europeans did act as consuls or trade representatives in Europe for sovereigns in North Africa and the Levant, but we will not be discussing them here. By the Treaty of Passarowitz (1718) between the Austro-Hungarian and Ottoman Empires, each side had the right to establish consulates. The first Ottoman consul, Kazgancizade Omer Aga, was dispatched to Vienna in 1725 , but the Austrians were opposed to a permanent Ottoman presence there: they did everything they could to have him recalled, and after they succeeded in $173^{2}$ no successor was named and the consulate lapsed. ${ }^{111}$ By 1802 several

\footnotetext{
105 The embassy was not received in Venice, and on arriving in Rome met with another Persian ambassador: Gil Fernández, El imperio, 2:59, 105, 123, 125; Alonso, "La embajada persa de Denguiz-Beg" and "El P. Antonio de Gouvea."

106 Gil Fernández, El imperio, 2:172-73.

107 Gil Fernández, El imperio, 2:284-88.

108 Gil Fernández, El imperio, 2:121-22.

109 Poumarède, "Soldats et envoyés"; Matthee, "Between Aloofness and Fascination"; Herbette, Une ambassade persane.

110 Ulbert, "Bibliographie: L'histoire de la fonction consulaire."

111 Wurm, "Enstehung und Aufhebung des osmanisches General-konsulates."
} 
European port cities had welcomed an Ottoman consul and/or trade representative: Marseille, Livorno, Naples, Venice, Ancona, Malta, Trieste, and Odessa. ${ }^{112}$ The same happened in some Spanish cities such as Barcelona, Palma de Mallorca, Alicante, and Cádiz; in many of those consulates the representative was a European.

It seems that North African consulates were not founded in Europe until the mid-nineteenth century. Morocco had a consular representative in the English port of Gibraltar from the early 180os. ${ }^{113}$ The same was true of Tunis, whose consulates appeared in Europe throughout the nineteenth century, particularly in Italy, France, and Belgium. ${ }^{114}$ The early French colonization of Algeria prevented that country from establishing any consulates in Europe.

The almost complete lack of permanent embassies and consulates of the Ottoman Empire, the North African Regencies, and Morocco in European ports and cities put those Muslim countries at a clear disadvantage in defending the interests of their merchants there, ${ }^{115}$ while existing capitulations already gave European tradesmen favorable treatment, compared to Muslims, in lands of Islam. The result was, as we have already observed, an asymmetrical relationship. ${ }^{116}$

In sum, during the three centuries that interest us the Ottoman Empire, Morocco, Algiers, Tunis, and Tripoli sent numerous embassies - probably more than three hundred - to Europe. They generally came with a considerable retinue of secretaries, interpreters, stewards, and others, including slaves. Since a group might be made up of as few as five individuals or as many as two hundred, we can speak of about six to seven thousand Muslim members of

112 Georgeon et al., Dictionnaire de l'Empire Ottoman, 292-93; Kuneralp, "Diplomates et consuls ottomans." The Ottoman Empire maintained a consulate general in Livorno and vice consuls in Cagliari, Genoa, and Villefranche: Cayci, "La question de la suppression des consulats."

113 Brown, "Anglo-Moroccan Relations." There is some mention of a representative of Sultan Muhammad bin Umar Bajja al-Hassani in Gibraltar early in the nineteenth century but after the Napoleonic wars: Erzini, "Hal yaslah li-taqansut (Is he suitable for consulship?)."

114 The Bey of Tunis had permanent agents in Europe, a vice consul in Nice from 1818 onward, and one in Malta from 1822: Cayci, "La question de la suppression"; Matrat, "La Société Pastré Frères”; Newman, “Tunisian Diplomatic Representation in Europe”; Smida, Consuls et consulats de Tunisie.

115 A good many treaties between Christian and Muslim nations mentioned the possibility of opening consulates from the latter in Europe. The peace treaty of 1685 between France and Tripoli contained a clause that allowed for a person of quality to reside in Marseille and oversee conformity with the treaty, but the clause was never applied, nor were similar ones for other North African countries: Valensi, Ces étrangers, 195.

116 Kaiser, "Asymétries méditerranéennes" and "La excepción permanente." 
delegations that moved through different European countries. Residents of cities and towns they traversed, excited by centuries-old stereotypes about Muslims, were fascinated by their showy, exotic dress and their customs, especially those related to food and eating. ${ }^{117}$ Many also brought strange animals as gifts for the sovereigns. Both the ambassadors and members of their delegations were intrigued in turn by all they saw on their travels between courts and their places of residence. ${ }^{118}$ We must imagine that the dialogue established by those mutual gazes signaled some approximation of two worlds that were not always so opposed as is normally thought - especially since some members of those retinues decided to remain in Europe instead of returning to their countries of origin, whether or not they converted to Christianity. We should compare those ruptures with their own world with those of Christians who decided to live out their lives in Islamic lands, most but not all of whom were renegades.

We must bear in mind that in the great majority of cases the embassy's objective was to settle naval disputes, or to arrange the ransom or exchange of slaves that each side held from the other.

We should also recall that some embassies gave rise to serious incidents, such as the slaughter of the Algerian delegation to Marseille in 1620; but there were many smaller clashes, sometimes provoked by the envoys themselves. Some behaved in ways offensive to their host countries; ${ }^{119}$ others claimed the rank of ambassador when they were no more than delegates, or demanded honors they did not deserve. ${ }^{120}$ We will see these same behaviors and arguments repeated with North African envoys to Spain in the eighteenth century.

117 Mehmed Effendi speaks of the expectations raised by his delegation of more than eighty persons in France in 1720-21: Le Paradis des infidèles, 69.

118 Lewis, The Muslim Discovery of Europe/Comment l'Islam a découvert l'Europe; Paradela Alonso, El otro laberinto español.

119 French authorities claimed that "The houses of the Turkish ambassador to Vienna are always guarded by soldiers, and this is the only way to stop the Turks' excessive license and debauchery. The memory of what took place every day in Paris with the Persian ambassador in 1715 shows the necessity of warning the subjects of such scandals, which are very difficult to remedy once they have arrived" "Les maisons de l' ambassadeur turc à Vienne sont toujours gardées de soldats, et l'on ne peût arrêter que par ce moyen la licence et la débauche excessives des Turcs. Le souvenir de ce qui se passa tous les jours à Paris chez l'ambassadeur de Perse en 1715 fait connaître la nécessité de prévenir les sujets de scandales auxquels il est très difficile de remédier lorsqu'ils sont arrivés"): Mehmed Effendi, Le Paradis, 10o. On the ambassador's interest in French women see Le Paradis, 37.

120 The Dutch court complained in 1645 that Mohamed ben Askar tried to pass for an ambassador when he was really a delegate: Caillé, "Ambassades et missions ... aux Pays-Bas," 62. Süleyman Aga provoked French protests when he insisted on being received at court as an ambassador in 1669: Veinstein, introd. to Mehmed Effendi, Le Paradis, 23. Mehmed Effendi himself was angry at being assigned a lower rank than the Persian ambassador, 
Members of European courts looked to the archives to learn how previous delegations had been received and how to act accordingly. ${ }^{121}$

In the light of these incidents and the expense of maintaining ambassadors and their retinues, European rulers showed little interest in receiving such embassies and often ordered their representatives in the Ottoman Empire and North Africa to do everything possible to prevent them. ${ }^{122}$

\subsection{Merchants in Ports and Cities}

Throughout our period there is documented activity by Muslim tradesmen in a number of European ports; while most of them were present only occasionally, others stayed for relatively long periods. They were far fewer in number, and lesser in the importance and volume of their business affairs, than the European merchants established in the Ottoman Levant and North Africa, again a clearly asymmetrical situation. ${ }^{123}$ Yet Muslim merchants in Europe in the Early Modern age were much more numerous than previously thought, and published research has demonstrated their presence in the principal port cities of the continent and even its interior. Most of them, though not all, engaged in small-scale commerce. These Muslim merchants also formed part of that initial groupe invisible that eventually became étrangers familiers, constituting a significant presence. ${ }^{124}$

Those merchants are difficult to identify in contemporary documents, however, making it hard to form a clear picture of Muslim commercial activity in European ports. But Venice clearly saw the greatest presence and activity by Muslim tradesmen, especially subjects of the Ottoman Empire, throughout our period. Especially active in the sixteenth and seventeenth centuries, ${ }^{125}$

who arrived in Paris in 1715 with a retinue of only ten or twelve followers, while Mehmed had more than eighty: Le Paradis, 37, 42.

121 Veinstein, introd. to Mehmed Effendi, Le Paradis, 3o. This was done when imposing a quarantine on the Ottoman ambasador and his escort when they arrived in Toulon (17 December 1720 to 25 January 1721), at a crucial moment when there was a plague epidemic in Marseille: Mehmed Effendi, Le Paradis, 30, 69.

122 When Mehmed Effendi's imminent voyage to Paris was announced, the French consul in Istanbul was instructed to dissuade the Turks from sending embassies to Europe by all means possible: Mehmed Effendi, Le Paradis, 3 .

123 Kaiser, "La excepción permanente."

124 Valensi, Ces étrangers familiers.

125 Minchela, Frontiere aperte; Pedani, "Venezia e l'Oriente" and "Presenze islamiche a Venezia"; Preto, Venezia e i Turchi; Kafadar, "A Death in Venice"; Vercellin, "Mercanti turchi a Venezia." 
they came to own a property in which to live and store their goods: the first Fondaco dei Turchi was created in 1575 and was joined by a second in $1621 .{ }^{126}$

We know that Muslim tradesmen stayed for varying periods in France, but there is little firm documentation. ${ }^{127}$ While they were never very numerous, their number obviously grew as the eighteenth century advanced. A traveler who passed through the port of Marseille noted streets full of "an infinite number of people from every country and of every condition, men and women: Turks, Greeks, Egyptian ladies, Moors." ${ }^{128}$ Among the characters in paintings of Marseille's port by Claude Joseph Vernet, especially in one dated 1754, there are several merchants in Oriental dress. ${ }^{129}$

Still, specific information about Muslim merchants is meager. Of the 489 foreign tradesmen established in Marseille during the eighteenth century only forty-three, fewer than ten percent, came from North Africa or the Levant, and most of those were Jews, Greeks, or Armenians. ${ }^{130}$ An examination of the city's Cahiers de Doléances de la Sénéchaussée for the second half of the century yields only fourteen Turks and Moors. ${ }^{131}$ We must conclude that scarcely any notable Muslim tradesmen settled in French ports, especially Marseille; those we find were probably on short visits as gens de passage or small businessmen (the reason we know little about them) who gave the Provençal port some of its famed local color. In 1620 there were two Tunisian and two Turkish tradesmen in the city during the "massacre of the Turks,"132 and after the tragedy other Tunisian and Algerian merchants asked the consuls in Marseille if it was safe to travel there. A Tunisian of Morisco origin appeared in person to try to recover what he could of the belongings of those killed. ${ }^{133}$

126 Bernardini, "Fondaco come fondamento di civiltà"; Burke, "Francesco di Demetri Litino"; Concina, Fondaci; Sagredo and Berchet, Il Fondaco dei Turchi. The presence of Persian merchants in Venice is also documented: Fechti Beg arrived there with loads of silk to sell in about 16o8: Gil Fernández, El Imperio, 1:166, 2:149.

127 In $1575^{-76}$ the ship captain Arnaut Mami signed powers of attorney in Marseille, and a certain Maumet from Tunis appears in a notarial document from Martigues in 1578: Kaiser, "Asymétries," 424, 439.

128 "Un nombre infini de gens de tous pays et de toute condition, hommes et femmes, des Turcs, des Grecs, des Égyptiennes, des Maures": Poumarède, "Négociants, voyageurs," 421.

129 One hangs in the Musée de la Marine in Paris.

130 Carrière, Négociants marseillais, 1:266-87.

131 Poumarède, "Négociants, voyageurs," 422.

132 The authorities saved their lives by putting them in prison; two other "pouvres hommes" were also jailed, along with the ambassador's official trumpeter. One of the merchants may have been Oumer Demelval: Kaiser, "Asymétries," 428-29, 433.

133 Kaiser, "Asymétries," 438. 
From the late seventeenth century we know of several Muslim merchants who traded in Marseille. One was the Tunisian Mohammad Ben Amor Tunisi, who was not well treated by the local authorities. ${ }^{134}$ A certain Omar, also from Tunis, dealt in gold dust and other goods there around 1709. Archam Benconolly, a Turk from the Regency of Algiers, lived at least four years in Marseille. ${ }^{135}$ In 1728 some Turks from Chania in Crete arrived there to sue a French merchant for non-payment of a shipment of oil he had bought from them. ${ }^{136}$ In 1757 a Turkish merchant of Tunis, Amour Ben Abdella, found it difficult to sell a cargo of wool that he had taken to Marseille on his own initiative. In 1759 permission was denied to an "Algerian Turk, son of the leader of the navy," when he wished to unload a shipment of silk fabric, and in the same year two Tunisian merchants with goods from Alexandria were quarantined in the lazzaretto. Two Moroccan businessmen spent a few months in Marseille in $1767 \cdot{ }^{137}$ During the War of the Convention between Spain and France (1793-1795), a number of French captains sold their ships to their Tunisian counterparts. Several Tunisian tradesmen worked in Marseille between 1799 and 1815, including H. Chaouch, S. Ben Yedder, Mohammed Bourras, Sahib Tabah, and Mohammed Morali, a captain who arrived at the head of a convoy of ships.

We should add to the above the members of Muslim diplomatic retinues who pursued commercial activity during their time in Europe. Two merchants from the Regency of Tunis joined the train of their embassy to Paris in 1803, led by Sidi Mustapha Arnaout. ${ }^{138}$

It was not always easy to engage in trade in Marseille. Mulla Osman had sold a load of wheat to the commissioner of the Toulon shipyard, who failed to pay him; he sued and had to wait two years for satisfaction. The Bey and his Prime Minister, Mustapha Khodja, intervened to defend Osman on two occasions, even asking help from the French Minister of Foreign Affairs; Khodja named his emissary M. Peritier as consul, although France resisted recognizing him as such. In 1819 Tunis sued again, to demand permanent representation in Marseille, while the Algerians argued that Article 21 of the treaty of 1720 gave them the right to name an agent in the city. ${ }^{139}$

\footnotetext{
134 Boubaker, La Régence de Tunis, 174; Poumarède, "Négociants," 421-22.

135 Desmet-Grégoire, Le Divan magique, 31.

136 Desmet-Grégoire, Le Divan magique, 31.

137 Kaiser, "Asymétries," 440-41.

138 Poumarède, "Négociants," 422. For how the North African merchant marine lost a valuable opportunity see Panzac, Les corsaires barbaresques.

139 Poumarède, "Négociants," 422; Tlili Sellaouti, "Laccueil des barbaresques"; DesmetGrégoire, Le Divan magique, 27.
} 
Maghrebi merchants and sailors arrived in other French ports as well. The interpreter Ruffin assisted several who reached the coasts of France without any resources. One, a merchant from Tripoli, was in Brest in 1778 after the English ship in which he was traveling was seized by a French corsair. The next year Ruffin helped another seven Muslims out of their difficulties. In November 1809 a Tunisian convoy with about four hundred crew members was forced into the port of Mahon by a storm, then was detained for three months in Marseille.

The port of Livorno apparently saw visits by Algerians, Tunisians, and Ottomans in the seventeenth and eighteenth centuries, though we have little information about them. As a free port it gave them complete liberty to carry out business there, at least in theory. ${ }^{140}$ In the first half of the seventeenth century Mohammad Quassadi and Mohammad Essowi served there as representatives of Mohammad Siala, the great Tunisian merchant from Sfax, who also launched several of his own ships toward that port. In 1615-1616 Gio Pérez (or Mohammad Giar or Sayyar), Domenico Fernández, and Ali Maldonatto, Moriscos resident in Tunis, traveled to Livorno on business. ${ }^{141}$

We know much more about Muslim tradesmen in Malta, called "a sort of Christian Algiers" because its galleys preyed constantly on Muslim ships. ${ }^{142}$ The Egyptian captain Homor Ben Selem, who had been enslaved on the island, made at least nine trips between Malta, the Levant, and North Africa. ${ }^{143}$ In the early seventeenth century Mohammad Nail, of Djerba, represented the interests of the Sfax merchant Mohammad Siala on Malta, and we know of another tradesman from Sfax, Sidi Balfai, who spent a short time on the island. The Tunisian Ibrahim Asfouri made journeys to Malta where, in addition to other business, he helped to ransom Maltese captives in Tunis and Muslims on Malta. Alhi Ben Mami, a Turk resident in Tunis, was conducting business in Malta in 1629. Two ship's captains dealt in oil: Hamed Ben Abdallah and captain Boueba of Djerba. Mohammad from Tunis also frequented Malta with his ship. ${ }^{144}$ In the 163 os and 164 os several Muslim tradesmen, with their own or other ships, received safe-conducts of varying lengths from the Order of Saint John to sell their cargoes on the island: they included Mihamet Bin Borham from Tripoli in Syria in 1633, Said Bin Chacem of Algiers in 1643, and Ahmed from Rhodes in 1646.145

\footnotetext{
140 Calafat and Santus, "Les avatars du 'Turc."

141 Boubaker, La Régence de Tunis, 171-73.

142 Fontenay, La Méditerranée, 324.

143 Brogini, Malte frontière, 394-96.

144 Boubaker, La Régence, 171-76.

145 Brogini, Malte, 656.
} 
Information about Muslim traders in Sicily - which was under Spanish rule in the sixteenth and seventeenth centuries - is scarcer, but they were certainly present there. Mohammed Corrath, a Tunisian merchant who lived with his wife in Palermo from 1607 to 1614 , owned a ship that plied between Palermo, Tunis, and Bizerte, and he too played a role in ransoming captives. ${ }^{146}$

There were Muslim merchants in Rome who arranged ransoms, ${ }^{147}$ as well as Persian tradesmen in England. ${ }^{148}$ In the port cities of Mahon and Gibraltar, under English rule from the early eighteenth century, Muslim traders were active throughout the 1700 . ${ }^{149}$ We have already seen how a Tunisian convoy with four hundred sailors took shelter from a storm in Mahon in 1809. In the same year a second Tunisian ship, under its captain Hadj Yahya, was also forced into safe harbor there. ${ }^{150}$

As S. Boubaker has demonstrated for Tunisians, Muslim merchants found it very difficult to live permanently and prosper in the ports of Marseille, Genoa, and Livorno. In those cities European and Jewish businessmen limited the activity of their North African competitors as much as they could, reducing their presence to short stays and their commerce to small-scale trading. These constraints on the merchants' free exercise of trade only strengthened as the seventeenth century advanced..$^{151}$

Ironically the ports that historians have seen as the most tolerant, especially Marseille and the free port of Livorno, were the ones that made life most difficult for Muslim merchants. The same was true of Malta - the "Christian Algiers," with its Order of Saint John - and of Sicily, ruled by Spain. Possibly in those places, at least in the seventeenth century, Muslim tradesmen planning to stay only briefly might have met fewer problems. But the same strictures came to apply, so that with rare exceptions there were few Muslims engaged in commerce on the northern shore of the Mediterranean.

\footnotetext{
146 Boubaker, La Régence, 175.

147 For instance Mehmet Agha, "mercator africanus," associated in 1582 with the Roman arciconfraternità del Gonfalone: Kaiser, "Asymétries," 423.

148 Robert Sherley sailed from England for Persia in 1613 with some Persians in his retinue: Gil Fernández, El imperio, 2:359; Davies, Elizabethans Errant; Penrose, The Sherleian Odyssey; Ross, Sir Anthony Sherley.

149 For Algerian ships that entered Mahon and Gibraltar see Martín Corrales, "Intercambios comerciales."

150 Tlili Sellaouti, "L'accueil des barbaresques"; Valensi, "Les relations commerciales"; Emerit, "Essai d'une marine marchande."

$15^{1}$ Boubaker, La Régence, 176; Kaiser reached the same conclusion in "Asymétries."
} 


\section{4}

\section{Muslim Converts to Christianity}

Muslim converts to Christianity are documented throughout our period and all across the European continent, though in far fewer numbers than the three hundred thousand Christian converts to Islam, or "renegades." 152 Information about Muslims is almost always isolated and scattered, so that it is hard to assess the true dimensions of the phenomenon. ${ }^{153}$

Leaving Spain aside, everything indicates that Italy saw the largest number of conversions in the Early Modern age: more than a thousand Muslims converted in Rome during our period, ${ }^{154}$ about five hundred in Naples from 1565 to $1828,{ }^{155}$ and about 310 in Florence from 1600 to $1800 .{ }^{156}$ We have notice of individual cases from other Italian cities such as Venice, ${ }^{157}$ Genoa, Livorno, Lucca, Catanzaro, and Turin. ${ }^{158}$

We also know of many baptized Muslims through Inquisition records: 124 "Moors" were charged in Sicily from 1541 to 1707 and twenty-two in Sardinia between 1570 and 1679 . Of course, those who were persecuted by the Holy Office were individuals who returned to their former faith in some form after having been baptized, ${ }^{159}$ so we should add to these figures the larger number who would have integrated fully into Christian society and presented no problems for the Inquisition.

Prominent Muslims who converted were the ones who made the greatest impact. One of the most famous was Muhammad el-Attassi, a native of Fez, who became Baldassare Loyola de Mandes after his conversion. Schooled in

\footnotetext{
152 Bennassar, Los cristianos de Alá.

153 Bono, Il Mediterraneo, esp. the chapter "Schiavi e convertiti da una riva all'altra," 79-110. Also Bono, "Conversioni di Musulmani" and "Maghrebini convertiti."

154 Nepi, "The Restitutiones ad libertatem"; Caffiero, "Battesimi, libertà e frontiere" and Battesimiforzati.

155 The exact number is 534, though some were not Muslims: Varriale, "Conversioni," "Tra il Mediterraneo e il fonte," and "La capital de la frontera"; Mazur, "Combating 'Mohammedan Indecency."

156 Marconcini, Por amor del cielo and "Una presenza nascosta."

157 Rothman, "Becoming Venetian."

158 Lenci, "Relazione del battesimo"; Sinopoli, "Conversioni di turchi." A "Turk from Anatolia," Gerolamo Motta, who was doubtless a convert, lived in Turin in the late seventeenth and early eighteenth centuries; he was personal tailor to Prince Eugene of Savoy and amassed a large fortune, which he left to the local charity hospital: Cerutti, Étrangers, esp. chap. 2. For some baptisms in Livorno in the 1600 see Galasso, Alle origini di una comunità, $141-43$.

159 I have not included the Moriscos, renegades, and pro-moros from the study that contains these figures: González-Raymond, La Croix et le Croissant; see also her "Les esclaves maures et l'Inquisition."
} 
the faith by Jesuits, he was destined for India to undertake the conversion of Muslims there, but died in Madrid on his way to embark at Lisbon in 1667.160

Another notable case was that of Hassan bin Muhammed al-Wazzan al-Fazi of Granada. Exiled to Fez with his family after his native city fell in 1492, he received an excellent education it its madrasa. In 1518, aged twenty-five and an experienced traveler, he was captured by corsairs and offered as a gift to the Pope on account of his great talents. Nominally converted to Christianity under the name Leone il Africano, he was a leading intellectual of his time. He is thought to have died in Tunis around 1554 after having embraced Islam once more. ${ }^{161}$

Several members of the Hafsid dynasty that ruled Tunis until 1574 opted for conversion after their exile to Naples and Sicily. Since they all accepted the protection of the Spanish monarchy and moved often between Spain and Italy, I will discuss them more fully in the chapter on converts in Spain.

Many Muslims also converted to Christianity in France, particularly in Paris. ${ }^{162}$ When the Ottoman ambassador visited the city in 1669 he attracted "a troop of Turks dressed in French clothing," among them "many Turks who had become Christians [and] wish to return with him to take up their former religion"; 163 one of them, "named Jean ... was baptized in Rome." A convert who became famous was Dominique de Saint-Thomas, known as "père Ottoman," though after his death he was considered an impostor. ${ }^{164}$ Another notable figure was Luis Ovanete, born in Istanbul, who arrived in France in the Ottoman ambassador's retinue in 1721. He served in the French army for several years, rising to the rank of lieutenant of infantry, and was naturalized in $1745 \cdot{ }^{165} \mathrm{We}$ hear of occasional conversions outside of Paris as well: in Marseille, ${ }^{166}$ Toulouse

160 Freller, "Osman and Muhammad el-Attaz"; Colombo, "A Muslim Turned Jesuit" and "Baldasarre Loyola Mandes"; Preste de Almeida, "De Fez à Loreto"; Alonso Acero, Sultanes, 107-08; García Goldáraz, "Un príncipe de Fez jesuita”; Lebessou, "La seconde vie d’un sultan."

161 Davis, Trickster Travels/León el Africano; Rauchenberger, Johannes Leo der Afrikaner; Berbrugger, "Études biographiques. Léon l'Africain."

162 A Turk converted in 1596. In 1604 four young Turks arrived in Paris accompanied by Trinitarian fathers; all were baptized and two became men of religion themselves: Mathorez, "Les éléments de population."

163 "Une troupe de Turcs habillés à la française. ... plusieurs Turcs qui se sont faits chrétiens veulent s'en retourner avec lui pour rentrer dans leur ancienne religion." Mehmed Effendi called them "Turcs mal convertis": Le Paradis, 23.

164 Poumarède, "Négociants, voyageurs," 420-21.

165 Poumarède, "Négociants," 423.

166 Claude Levantin, certainly a Muslim, was a translator in Marseille from 1571 to 1596 and converted. We shall speak further on of galley slaves who converted: Mathorez, "Les éléments." 
(nine cases), ${ }^{167}$ Cassis (two), ${ }^{168}$ and one each in Nantes, La Rochelle, Ablon, ${ }^{169}$ and Orthez. ${ }^{170}$ Occasionally galley slaves also converted: one in $1647,{ }^{171}$ five between 1685 and $1687,{ }^{172}$ and another in $1718 .{ }^{173}$

More studies are now being published of Muslim converts in Portugal: some were North Africans who accepted Christianity in Portuguese ports on the Moroccan coast, ${ }^{174}$ while others converted in cities in Portugal. ${ }^{175}$

We are beginning to learn more about conversions in Malta, where some Muslims turned Christian in hopes of easing their burden of slavery. Others were baptized on their deathbeds - a fact that reveals more about the excessive zeal of Christian priests who attended them than about their own wishes. ${ }^{176}$

There are recorded cases of Muslims who converted in England. ${ }^{177}$ Among Muslims converted in the Low Countries was Mullé Bamet, who claimed to be "the son of Muley Mahomet, king of Morocco," though he may have been an impostor. In 1603, at the age of thirty-nine and using the name Enrique Xerife "prince of Morocco," he joined a reformed Christian sect and entered the service of the Prince of Nassau. He requested and received a commission in the Dutch cavalry, granted by the Estates General. ${ }^{178} \mathrm{~A}$ few Muslims were also baptized in German states. ${ }^{179}$

We have not yet determined how many of these conversions were sincere or self-interested, voluntary or forced; but the change of religion is still significant. In most cases these new Christians took an irrevocable step. In any event, the fragmentary data we have collected should confirm that conversion to Christianity was not as rare as has been claimed, and that it represented a clear parallel to conversion to Islam by renegades.

167 They escaped from Spanish galleys in 1644 near Bayonne: Mathorez, "Les éléments."

168 One of the abovementioned escapees from Bayonne in 1644: Mathorez, "Les éléments," 197. Also Jean de Morea, baptized in Cassis in 169o: Desmet-Grégoire, Le Divan, 25.

169 A fifteen-year-old youth in Nantes; an Algerian in La Rochelle in 1655; and a forty-year-old Turk baptized by Protestants in Ablon in 1604: Mathorez, "Les éléments," 195-97.

170 Couture, "Baptême d'un Turc," 90.

171 Mathorez, "Les élements," 197.

172 Two Islamized black Africans (one of them from Morocco), an Egyptian, a Turk from Constantinople and another from Epirus: Boyer, "La chiourme," 72-73.

173 Desmet-Grégoire, Le Divan, 34.

174 Rosenberger, "Mouriscos et elches"; Bouchareb, "Les conséquences."

175 Rodriguez da Silva Tavim, "Educating the Infidels Within"; Ricard, "Louis de Grenade."

176 There were various instances in 1654-55: Brogini, Malte, 685 .

177 Dakhlia, "Assujettis au baptême?", 172-73.

178 Alonso Acero, Sultanes, 105-o6; Coste, "Un Prince tunisien converti."

179 Schunka, "Türken taufen in Thüringen." 


\subsection{Exiles, Travelers, Soldiers, and Adventurers}

Muslim exiles were present in Europe throughout the period under study. Possibly the most important was Sultan Djem (or Prince Cem or Zizimo), born in 1459 as the third son of Caliph Mehmet II, the conqueror of Constantinople. On his father's death he was defeated by his first-born brother, Bayezid, in the struggle for the throne. With his followers he sought refuge in Malta among the Knights of Saint John, who sent him as a virtual hostage to the French court. In 1489 he was placed under the protection (or the vigilant eye) of the Pope in Rome, and when Charles viII of France arrived in Rome on his campaign of Italian conquest he took Djem with him to Naples. There he died, almost certainly poisoned, without ever having converted to Christianity. ${ }^{180}$

A prominent figure in the early 1600 s was Fakhr el-Din, a Druze leader who became governor of Chouf in Lebanon. At a time of violent internal struggles in the region, the Grand Vizier in Istanbul sent troops against him and he fled; sailing from Sidon to Tuscany in 1612, he was received by Grand Duke Cosimo II, with whom he had already been in diplomatic contact. He hoped that Cosimo would offer military help against his enemies in Lebanon in exchange for Tuscan influence there, and while he failed in that goal he did steep himself in Renaissance culture. Afterward he lived for three years in Sicily. In 1618, when the situation in his homeland had improved, he returned there and recovered his post, enlarging the governorate to Mount Lebanon and Latakia. After many battles to preserve and augment his power he was defeated by Ottoman troops and taken to Constantinople, where he was executed in $1635 .{ }^{181}$

The largest group of Muslim exiles in Europe, however, was made up of members of the ruling Maghrebi dynasties (Zayyanids, Hafsids, Saadids, and Wattasids) who had been deposed and sought to regain their thrones. Most of them found refuge - perhaps not in the conditions they had expected - in either Spain or the territories it held in the sixteenth and seventeenth centuries: Naples, Sicily, and Portugal. I will touch on them briefly here and return to them at greater length in Chapter 4.

Abu Hassun, head of the Wattasid dynasty, was defeated by the Saadids in 1549; he went to Portugal and with help from there returned to Morocco in 1554. In that year he fell in battle against Muhammad al-Shaykh al-Mahdi. ${ }^{182}$

180 Vatin, Sultan Djem; Boscolo, "Le vicissitudini di Cem”; Rainero, "La prigionia e la morte del Sultano Gem”; Inalcik, "A Case Study”; Ertaylan, Sultan Cem; Thuasne, Djem Sultan.

181 Gorton, Renaissance Emir; El Bibas, L'Emiro e il Granduca; Cuffaro, "Fakhr ad-Din II alla corte dei Medici"; Caroli, Fakhr ad-Din II.

182 Alonso Acero, Sultanes, 66-79. 
His grandson, baptized with the name Gaspar de Benimerin, served the Spanish monarchy on the Indies run and on the islands of Santiago, Cabo Verde, and Terceira, as well as in Flanders, Naples, and Hungary. He settled in Naples where, supported by Carlos Gonzaga, Duke of Nevers, he created a new military order, the Milicia Cristiana. On his death in 1641 he was buried in the church of Santa María de la Concordia in Naples. ${ }^{183}$

Some members of the Saadid dynasty also sought refuge in Europe. In 1574 Abu Abdallah Muhammad ibn Abdallah al-Mutawakkil fled from his uncles Abd al-Malik ("el Maluco") and Ahmad, who expelled him from Fez and Marrakech in 1576. He found military and financial support in Portugal and returned to Morocco, where he perished in the Battle of the Three Kings (Alcazarquivir). ${ }^{184}$ His son Muley Shaykh (Xeque) and the latter's uncle Muley Nazar (Nsar) were sent to Lisbon, where they lived for ten years surrounded by relatives and a large retinue. Philip II used them to pressure the Moroccan Sultan Ahmad al-Mansur; the sultan retaliated by negotiating with the prior of Crato, Don Antonio, who was seeking help from Morocco and England to recover the Portuguese throne. ${ }^{185}$ Muley Xeque was eventually baptized as Felipe de África or Austria and saw military service in Flanders and Milan, dying near that city. ${ }^{186}$ His uncle Muley Nsar, who considered himself the only legitimate pretender to the throne, returned to Morocco in 1595, but lacking military or financial support from Spain he lost his life there in $1596 .{ }^{187}$

The son of Sultan al-Mansur, Muhammad al-Shaykh (Muley Xeque), fought his brothers Muley Zidan and Abu Faris for control of all Morocco but was forced to flee to Portugal, arriving in Villa Nova de Portimão in 16og. With Spanish help he was able to return to Morocco and vanquish his brothers, ceding the Spaniards the fortified port of Larache in exchange. ${ }^{188}$

183 Varriale, "La media luna al revés"; Alonso Acero, Sultanes, 79-88; Viguera, "Noticias sobre el Magreb"; Castries, "Trois princes marocains convertis"; Escallon [Scaglione], Origen y descendencia.

184 Alonso Acero, Sultanes, 91-92; Valensi, Fables de la mémoire and "Silence, dénegation"; Berthier, La Bataille de l'Oued el-Makhazen; Nekrouf, La Bataille des Trois Rois; Bovill, The Battle of Alcazar.

185 Alonso Acero, Sultanes, 98-100.

186 Alonso Acero, Sultanes, 98-10o. For Muley Xeque's letters to the Spanish monarch see García-Arenal et al., Cartas marruecas. La Véronne, "Séjour en Andalousie de deux princes"; Guastavino Gallent, "Don Felipe de África”; Oliver Asín, Vida de don Felipe de África.

187 Alonso Acero, Sultanes, 92, 94; La Véronne, "Séjour."

188 Alonso Acero, Sultanes, 102-05. 
Abd al-Karim Ibn Tuda, of the family that ruled Alcazarquivir, Larache, and Arcila, was a relative and supporter of al-Mutawakkil. He was dispatched to Lisbon in 1578 with Sidi Hammu, the former governor of Meknes. They were eventually able to return to Morocco. 189

The Hafsid dynasty also had its exiles. Muley Hassan, the king of Tunis deposed by the Ottomans in 1534, was restored to his throne the following year by Charles v. ${ }^{190}$ When he traveled to Augsburg to seek Charles's support, his son Hamida took advantage of his absence to proclaim himself king, and on his father's return defeated and blinded him. Muley Hassan managed to leave Tunis, living out his life in Sicily and Naples until his death around 1550. A son who lived with him in Sicily, Muley Bucar, was captured by an Ottoman galley in $155^{1}$ and taken to Istanbul. ${ }^{191}$ Meanwhile Hamida was ousted from Tunis by the Ottomans in 1569 and fled to Italy. When Spain reconquered his city in 1573 it placed the former king's brother Muley Muhammad on the throne, while Hamida and his partisans, conveyed to Naples as captives, were set free in Sicily. During the new Ottoman conquest of Tunis Hamida tried to return and reclaim his throne but died of the plague, leaving a widow and two sons. He bequeathed most of his fortune to one of them, known as "El Cojo" (the Lame), who had expressed a wish to return to Tunis and live as a Muslim; the other son, also called Hamida, had provoked his father's anger and near-disinheritance by expressing a wish to be baptized while he lived in Naples. Hamida the younger received baptism in August 1575, a few days after his father's death, taking the name Carlos de Austria and with Don John of Austria as his godfather. He was the support of his mother and other family members. On becoming an officer of the galleys of Naples he designed a coat of arms that showed a lance between two swords and above them a downward-facing crescent moon that symbolized his rejection of Islam. At his death in 1601 he left his estate to the monastery of Santa María la Nueva in Naples, run by minor friars of the Franciscan order. With his wife Luisa de Austria he had a son, Enrique de Austria, "grandson of King Amida of Tunis," who was baptized at birth. ${ }^{192}$

Other members of the same family appear in the sources. A man who claimed to be Carlos de Austria's brother was baptized during Philip II's reign. He lived with his wife Virginia in Sicily, and in around 1605-06 wrote to Philip III lamenting his financial difficulties. ${ }^{193}$

189 Cabanelas, "El caíd marroquí 'Abd al-Karim."

190 Boubaker, "Le traité hispano-hafside."

191 Alonso Acero, Sultanes, 139-42.

192 Alonso Acero, Sultanes, 142-46; Monchicourt, "Études kairouanaises."

193 Alonso Acero, Sultanes, 146-47. 
Descendants of Muley Muhammad, whom the Spanish had placed on the throne of Tunis in 1573, included his oldest son Muley Nazar, who had lived in Sicily and died in battle in Tunis. Another son, Muley Abderrahman, was in Palermo in 1574 in charge of three of his father's wives, two of his brother's, and a number of servants. Muley Abderrahman did not relinquish a claim to the throne: in 1594 he claimed to have support from several sheikhs and holy men as well as sixty thousand partisans, but the Viceroy of Sicily did not trust him. His death in that year extinguished the last hopes of any Hafsid return to power in Tunis. ${ }^{194}$

Muley Ahmad, son of Muley Abu Abdallah and brother of Muley Hassan, lived in Sicily from an early age. In 1570 he proposed himself to Philip II as the ideal candidate to expel the Turks from Tunis, and offered his four wives and seven children as hostages in exchange for help in regaining the throne. In 1581 he went with his oldest son Muley Memu to Tunis, where after several years of struggle they were both captured in 1592 and sent to Istanbul, dying in prison there. ${ }^{195}$ Also in 1592 another descendant of Muley Ahmed, also called Muley Hassan, asked financial help from Philip II for himself and his other family members who were still in Sicily. There were three sisters, one of whom was baptized in 1588 in the chapel of the royal palace at Palermo, taking the name María. There were also three wives of Muley Ahmed: one named Embarca, with her son, and another whose name is unknown with an unmarried daughter. Guademala, wife of Muley Muhammad who had been deposed in 1574, was caring for a granddaughter in Sicily. ${ }^{196}$

Other exiles came from the Zayyanid dynasty. Muley el-Nasser el-Thabti (Muley Nazar), son of the king who had reigned in Tlemcen from 1521 to 1534, fled from the Saadid offensive and sought help from the Spaniards, taking refuge with his family and followers in Oran in 1551. There he spent several years while his pleas for help to reclaim the throne went unattended. ${ }^{197}$ His brothers Muley Ahmed and Muley Hassan joined him in exile in Oran. ${ }^{198}$

Moriscos expelled from Spain between 1609 and 1614 passed through several European countries, usually only briefly. Their presence was felt most strongly in France. King Henry IV, who maintained contacts with Moriscos from Valencia, allowed them passage in their travels toward North Africa and the Ottoman Levant; at the same time he decreed that those who wished to stay had

\footnotetext{
194 Alonso Acero, Sultanes, 148-49.

195 Alonso Acero, Sultanes, 149-51.

196 Alonso Acero, Sultanes, 151.

197 Alonso Acero, Sultanes, 113-14.

198 Tarruell, Oran y don Carlos, 283.
} 
to renounce Islam ${ }^{199}$ and could not settle south of the Dordogne and Garonne rivers. Bordeaux and Toulouse placed obstacles to Morisco passage and settlement, though small groups managed to remain in Languedoc, Béarn, Guyenne, Paris, Bordeaux, Biarritz, Montpellier, Marseille, and Olliules. ${ }^{200}$ We also have record of their presence elsewhere in Europe: in Portugal, ${ }^{201}$ Genoa, Rome, Naples, Livorno, ${ }^{202}$ and Holland. ${ }^{203}$

Muslim travelers also passed through Europe in the Early Modern period, and we have spoken of some of them above, particularly those who accompanied embassies. ${ }^{204}$ One of the most significant, since he left a written account of his impressions, was Ahmad Ibn Qasim al-Hajari, who visited France and the Low Countries in the seventeenth century. ${ }^{205}$

There is a growing bibliography on free Muslims who lived in or traveled through different European countries. There were exiles, slaves who had gained their freedom through self-purchase or their owners' decisions, members of diplomatic missions, and others who spent long periods in Europe. Some of them declined to return to their countries of origin and lived out their lives in Europe, whether or not they changed their religion.

In France we must take account of military men, especially the thirty thousand Turkish Janissaries and sailors of the Ottoman fleet under Barbarossa that wintered in Toulon from September 1543 to March 1544. The French king, fearing that prolonged contact between the Ottoman troops and the local population would cause violence, ordered the town (whose population was about five thousand at the time) emptied and manned with allied troops, though the evacuation was never complete. Local residents complained to the king about losses of goods and property because of the Turks, but they do not seem to have suffered unduly. ${ }^{206}$

199 The measure applied to all Muslims, not only Moriscos: Mathorez, "Les éléments," esp. 194.

200 Michel, "Les morisques en France"; Santoni, "Le passage des morisques"; Turbet-Delof, "Documents sur la diaspora morisque"; Temimi, "Le passage des morisques à Marseille"; Gafsi and Mohieddine, "À propos du passage des morisques"; Cardaillac, "Morisques en Provence" and "Procès pour abus contre les morisques"; Ricau, "Lexpulsion des morisques espagnols"; Mathorez, "Les élements."

201 Bouchard, Os pseudo-moriscos de Portugal and "Spécificité du problème morisque au Portugal"; Mendes Drumond Braga, Mouriscos e cristiãos no Portugal.

202 Pomara Saverino, "I rifugiati. I moriscos e l'Italia" and "Cristianos malos?"; Temimi, "Le passage des morisques."

203 Caillé, "Ambassades et missions ... aux Pays-Bas," 58-59.

204 Newman, "Arab Travellers to Europe."

205 Al-Hajari, Kitâb Nasir al-Dîn.

206 Poumarède, "Soldats et envoyés"; Isom-Verhaaren, "Barbarossa and his Army"; Deny and Laroche, "L'expedition en Provence." 
In the eighteenth century the French Regiment of Saxe-Volontaire - created in 1743 and dissolved in 1745 - accepted Turks and Tatars as long as they professed the religion of Islam. ${ }^{207}$

There are also a few cases of civilians such as Isaac Bey, who in the 1770 s assisted the interpreter P. Ruffin, receiving a pension from the king. There was a legion of interpreters, domestic servants, adventurers, and others in several European cities, among them Paris and Marseille. ${ }^{208}$ It was not common for Muslims, whether Maghrebi or Turkish, to be naturalized in France, since it required renouncing Islam, though there were occasional cases from the sixteenth to the eighteenth centuries. ${ }^{209}$

In sixteenth-century Naples an area near the harbor was known as the Fondaco dei Mori, frequented by slaves from the shipyard and the galleys as well as by free Muslims. ${ }^{210}$ Some freedmen also lived in Livorno. ${ }^{211}$ In Malta, as in Naples, the number of free Muslims was considerable, as is confirmed by the Order of Saint John's decree to expel them in $1645 .{ }^{212}$ We know of some Muslims in the Low Countries, among them former slaves whom the Dutch freed from their Spanish masters. ${ }^{213}$

It is hard to establish the true number and significance of Muslims - slave or free, converted or not - who visited or settled in the various European countries. Almost four decades ago G. Veinstein thought that they were very few:

Movement of men usually occurs in only one direction: it is Westerners who - whether merchants, pilgrims, refugees, or renegades in the Sultan's

207 Poumarède, "Négociants, voyageurs," 422.

208 Poumarède, "Négociants," 421; Desmet-Grégoire, Le Divan magique, 26-27.

209 Some Turks were naturalized and baptized around 1524. In the early 1600 s Marie de Médicis employed at least one male and three female Turks, possibly free persons, in her tapestry workshops. Two Turks belonging to the king's guard were naturalized around 1647 , as were two Turks in 1709 , one in 1711 , two in 1720 , one in 1749 , and two in 1750: Mathorez, "Les éléments."

210 Varriale, "Conversioni" and "Tra il Mediterraneo."

211 Galasso, Alle origini, 142.

212 Brogini, Malte, 665.

213 One was Mohammad Ould Aicha, a native of Fez who, as a slave in Cádiz in 1596, was freed by the Dutch who beseiged and destroyed the city; after living for some time as the guest of an Amsterdam merchant, he was eventually taken to Morocco. When the Spaniards abandoned the city of Sluis in 1604 the Dutch found about one hundred Muslim slaves, whom they took to Morocco the next year, landing them in Safi: Caillé, "Ambassadeurs, chargés de missions." 
service - guarantee contact between the West and the East; the opposite is exceptional. ${ }^{214}$

Twenty-five years later, and speaking only of France, G. Poumarède believed that Muslim presence there in the Early Modern age had been scarce, with only sporadic and isolated cases:

The Muslim presence is therefore a reflection of the relationships woven between France and the Ottoman, Persian, and North African worlds. The political and diplomatic ties that unite them explain the presence of thirty thousand Turks in Toulon in 1543 and the passage of the Eastern ambassadors who visit the court throughout the sixteenth, seventeenth, and eighteenth centuries. In the same way, stays by Muslim tradesmen in the kingdom's port cities are explained by the expansion and intensification of France's commercial relations with the rest of the Mediterranean. The employment of slaves from Islamic countries in the galleys recalls how far these relations are also marked by tensions, rivalries, and sometimes declared conflicts. Under these conditions the Muslim presence remains very small and often ephemeral. While it underlines the genuine progress of familiarity between East and West, at the same time it reveals the limits of that rapprochement. ${ }^{215}$

From what we have laid out here, however, the presence of Muslims does not seem to have been so very marginal, or we could not explain the existence of

214 "Le mouvement des hommes se fait presque en sens unique: ce sont les Occidentaux qui, marchands, pèlerins, réfugiés, renégats au service du Sultan, assurent le contact entre l'Occident et l'Orient; l'inverse est exceptionnel." Although he is speaking of travels between the West and the Ottoman Empire, his thought also applies to North Africa: Veinstein, "Introduction" to Mehmet Effendi, 10.

215 "La présence musulmane est ainsi à l'image des relations tissés entre la France et les mondes otomans, perse et barbaresque. Les liens politiques et diplomatiques qui les unissent expliquent la présence de 30.000 Turcs à Toulon en 1543 ou le passage de ces ambassades orientales que se rendent à la cour tout au long des XVIe, XVIIe et XVIIIe siècles. De même, le séjour de négociants musulmans dans les ports du royaume se justifie par l'essor et l'intensification des relations commerciales de la France avec l'ensemble du bassin méditerranéen. Quant à l'utilisation d'esclaves originaires des pays d'Islam sur les galères, elle rappelle combien ces rapports sont aussi marqués par des tensions, des rivalités et parfois des conflits déclarés. Dans ces conditions, la présence musulmane reste infime et souvent éphémère. Elle souligne les progrès réels d'une familiarité entre l'Orient et l'Occident, mais révèle en même temps les limites d'un tel rapprochement": Poumarède, "Négociants," 425. 
sites where they lived and engaged in commerce, such as the Fondaco dei Turchi in Venice and the Fondaco dei Mori in Naples; places of worship or mosques, whether tolerated or clandestine (the mosque in Naples, the Prison des Esclaves in Malta); or Islamic burial grounds (at Venice, Marseille, Toulon, and Naples). ${ }^{216}$ Malta was the exception: after rebuffing the Turkish assault in 1565 the island considered itself a sacred space and forbade any Muslim or Jewish interments. ${ }^{217}$ Obviously, however, Muslim slaves who died on Malta must have been buried there, probably on the beaches - that was the case in Spain, as we shall see.

There is no doubt that the largest group of Muslims who lived for any period in Europe, willingly or unwillingly, in the sixteenth to eighteenth centuries was made up of slaves; they were far more numerous than all the ambassadors, merchants, exiles, converts, and adventurers put together. It bears repeating that there were many more Muslim slaves in Spain, Italy, Malta, and Portugal than in France, England, the Low Countries, and northern Europe in general.

It is striking that there were so few Muslim tradesmen in European ports that maintained peaceful relations with Islamic countries, ratified by treaties and capitulations. It is logical that we have little information from northern ports, but strange in the case of French ports, especially Marseille, and the free port of Livorno. There was no interest in encouraging Muslim traders to settle there, though we have no studies to confirm the fact. Was the situation different in Italian, Maltese, Spanish, and Portuguese ports? We cannot be certain. But in the latter group Muslims may have had somewhat more freedom to settle and trade, at least in the sixteenth and seventeenth centuries. If that proves true, then paradoxically it would be the countries assumed to show the strongest religious intolerance toward Muslims that most tended to accept their presence, always with certain limitations.

For the moment W. Kaiser seems to offer the best interpretation of this clear asymmetry in Christian-Muslim relations. He suggests that in the sixteenth and seventeenth centuries, when diplomatic treaties guaranteed no reciprocity (and were usually violated in any case), the void was filled by the principles of war, a code of honor, and traditional hospitality:

In the absence of reciprocity ensured by diplomatic treaties, this principle - arising from war and a code of honor assumed to be shared, as well

216 Lucchetta, "Note intorno a un elenco"; Babinger, "Dâvûd-Celebi"; Bertran, "Les cimetières." 217 Brogini, Malte, 684. 
as customary hospitality - creates a secure though fragile framework for Muslim merchants who reside in or pass through European ports [and] who can expect to receive "favors and good treatment." ${ }^{218}$

In other words, the Treaties and Capitulations signed with the French, English, and Dutch did not guarantee reciprocity for subjects of the Ottoman Empire, the North African Regencies, and Morocco in the ports of those states. In Marseille, London, Amsterdam and elsewhere in northern Europe, activity by Maghrebi and Ottoman merchants received no protection. The same was true of Livorno, which was open to any tradesman irrespective of his religion. Clauses in the treaties that proved inconvenient to Europeans were almost always ignored. Nonetheless, the proliferation of treaties of peace and commerce in the 1700 s favored some degree of commercial activity by Muslims in the aforementioned ports.

Paradoxically, compensation for the absence of treaties took the form of a principle of warfare that guaranteed a certain reciprocity; it was matched by a code of honor and customary hospitality that allowed more space for activity by Muslims in Spanish, Italian, Maltese, and Portuguese ports. The determining factor was the dominance of trade in those markets:

In the eighteenth century the principle of reciprocity, now well established by diplomatic agreements with the Maghrebi regencies, remains troublesome as to freedom of worship; and it is viewed openly as an obstacle to commerce, an obstacle that everyone tries to bypass in order to estalish dominance in all exchanges with the Maghreb. ${ }^{219}$

Even keeping all this in mind, it is clear that the impact of Muslim presence was very different in northern and southern Europe. In the countries of the "northern invasion," France included, there was no significant number of slaves, merchants, or free Muslims, baptized or not. Perhaps this explains why, in those countries' imaginary, the figure of the exotic ambassador held sway: in spite of the luxury in which such men traveled they lived off the bounty of the courts they visited, leading to the notion that they were greedy for gifts and

218 Kaiser, "Asymétries," 442.

219 "Le principe de la réciprocité au XVIIIe siècle, désormais bien établi dans les accords diplomatiques avec les régences du Maghreb, reste gênant en ce qui concerne la liberté de culte, et il est franchement considéré comme un obstacle dans le commerce, obstacle que chacun tente de conturner afin d'établir sa domination dans les échanges avec le Maghreb": Kaiser, "Asymétries," 442. 
favors. This is the caricature we see in Shakespeare and Molière. Edward Said based his fundamental book Orientalism, at least in part, on this vision of the Muslim, whom we could think of as one who is arrayed for a festival. 220

In Spain and its dominions (Naples, Sicily, Sardinia, Malta, Portugal) there was also an impression of "exotic" ambassadors and they were likewise considered avaricious - more in the courts at Valladolid and Madrid than along the coasts. But this role in the national imaginary was countered to some extent by actual, physical, daily coexistence - marked by more or less tolerance with tens of thousands of slaves, hundreds of exiles and their families, many tradesmen, and thousands of immigrants, converts, and adventurers. ${ }^{221}$ People formed an image of them that, while still negative, had more facets than that held by northern Europeans. It was also formed much closer to home. ${ }^{222}$ Aside from the exoticism of the ambassadors and certain exiles, the prevailing view was of the Muslim enslaved, impoverished, and submissive - but someone with whom negotiation was possible. In the south and along the Mediterranean frontier the Muslim was a neighbor, and though he might be a slave or an infidel he formed part of the society that enslaved and marginalized him. His image in Spain was not so different from that of other marginalized groups such as gypsies, Moriscos or New Christians, paupers, and convicts. Finally we must stress once again, as we shall see in the following chapters, that the Muslim presence in Europe, particularly in Spain, was more significant than has previously been thought.

220 Said, Orientalism.

221 We should consider how relationships between slaves and freed Muslims (converted or not), a common phenomenon on both shores of the Mediterranean, increased the opportunities for slaves to interact with the society that had robbed them of their freedom: Boccadamo, Napoli e l'Islam; Tarruell, "Circulations," 198.

222 This in spite of the hostility that Muslims inspired at the same time, together with the "excesses of the Inquisition": religious persecution as a founding element of the state: Bernal Rodríguez, Monarquía e Imperio, 195. 